\title{
Temporal and Spatial Distribution of Zooplankton Inhabiting Sandy and Muddy Shore Habitats at Jazan Coastal Area
}

\author{
A.T. AbdAllah *(**)†, A.M. Alhababy*, M.G. Shamsy*, M.S. AbdelDayem* and Sahar H. Haroun*(***) \\ *Biology Department, Faculty of Science, Jazan University, Saudi Arabia \\ **Zoology Department, Faculty of Science, Al-Azhar University, Assiut, Egypt \\ ***Department of Biological and Geological Sciences, Faculty of Education, Ain Shams University, Egypt \\ $\dagger$ Corresponding author: A.T. AbdAllah: abdallaht.63@gmail.com
}

Nat. Env. \& Poll. Tech.

Website: www.neptjournal.com

Received: $10-12-2020$

Revised: 19-02-2021

Accepted: 24-02-2021

Key Words:

Zooplankton

Seasonal abundance

Sandy shore

Turfa peninsula

Almarjan

\section{ABSTRACT}

Few studies were made about zooplankton distribution in Jazan coastal area. The present study dealt with the identification of zooplankton at the sandy shore (AISalwa coast) and mangrove muddy shore (Turfa peninsula) at the Almarjan coast. Species richness and population density at different seasons were determined for both study areas between May 2016-April 2017. Conductivity, pH, water temperature, and salinity were measured. The relationship between water characters and the seasonal abundance of zooplankton seasons was examined through regression analysis. Ciliates, Rotifers, Nauplius larva, Gammarus sp., Veliger larva, Nematodes, Planaria, Copepods, and Kinorhyncha were recorded for both study areas. The highest species richness and population density were recorded during the summer season for Almarjan sandy shore and Turfa peninsula mangrove. Ciliates were the most abundant zooplankton on the sandy shore, while Kinorhyncha was the least abundant. The zooplankton Nematode was the most abundant at the Turfa Peninsula mangrove, whereas Gnathostomulida was the least abundant. Conductivity, salinity, and water temperature showed a significant regression relationship $(P<0.05)$ with zooplankton abundance. Data was discussed to highlight the role of zooplankton abundance in the mangrove and sandy shore ecosystem.

\section{INTRODUCTION}

Zooplankton has well known important ecological role in the marine ecosystem. They are the primary consumers in the marine food web. Zooplankton lives at depths up to 350 meters below the water surface (Castro \& Huber 2012, Lee \& Stokes 2006). Zooplankton performs dual vertical migration; upward at daylight to follow their prey; upward during the day to follow their prey, the phytoplankton, and downward at night to avoid predators (Castro \& Huber 2012).

Zooplankton is the main food source for fishes and other intertidal and epipelagic animals (Lee \& Stokes 2006). They live in littoral and sublittoral zones. Marine plankton is classified as "oceanic plankton" (plankters inhabiting water beyond continental shelves), "neritic plankton" (plankters inhabiting water overlying continental shelves), and "brackish-water plankton" (plankters inhabiting brackish-water areas such as estuaries and mangrove). According to the duration of planktonic life, zooplankton is classified into two groups holoplankton and meroplankton. The permanent members of animal plankton are called holoplankton. Meroplanktons are temporary members of the zooplankton, spending only part of their lifetimes as plankton such as larvae of fish, and arthropods. These larvae differ completely from adult stages at their mode of living as adults either live on the bottom or swim as nektons (Nybakken 1997).

Several authors have defined zooplankton based on morphological criteria (Bradford-Grieve et al. 1983, Heron \& Bradford-Grieve 1995, Lee \& Stokes, 2006 and Hickman et al. 2011). Kim et al. (2020) used DNA metabarcoding technique to identify zooplankton using the primer $(1391 \mathrm{~F}$ (50-GTACACACCGCCCGTC-30) and EukBr (50TGATCCTTCTGCAGGTTCAC CTAC-30).

Seasonal changes affect the biodiversity of zooplankton and the factors that control their distribution was previously studied by Manickam et al. (2018) and Sharma \& Kumari (2018).

Little work was made about the identification of zooplankton in Jazan. Previous studies on the Farasan Islands reported that copepods are the major constituents of the zooplankton community at the water surface (Farasan Report 2000, Abu-Zinada 2001). Calanoid and Euphausiid were recorded as the most important zooplankton as a food source for bream fish in Jazan in the red sea (Bakhsh 1994, Abdul Azis et al. 2003 and ObuidAllah et al. 2005). 
The present work concerns investigating seasonal distribution and abundance of zooplankton inhabiting surface water of intertidal areas on Almarjan sandy shore and mangrove area (Turfa peninsula). Species richness and diversity index were determined. Data were discussed to evaluate the effect of seasonal changes on the distribution of zooplankton in the sandy and muddy mangrove coastal marine ecosystem.

\section{MATERIALS AND METHODS}

\section{Study Area}

Almarjan sandy shore coast and Almarjan mangrove were the studied sites $\left(\mathrm{E} 42^{\circ} 33^{\prime} \mathrm{N} 16^{\prime} 90\right)$

\section{Sampling}

Zooplankton samples were collected seasonally from the littoral zone at the sandy shore of Almarjan coast, and at the mangrove of Almarjan coast about 10:00 am during the period; May 2016- April 2017. Plankton net 353 $\mu$ (Forestry Supplies) was used for this purpose. Identification of Zooplanktons was according to Bradford-Grieve et al. (1983), Heron and Bradford-Grieve (1995), Lee \& Stokes (2006), and Hickman et al. (2011).

\section{Water Characteristics}

Physical and chemical water criteria were measured at littoral areas of Almarjan sandy shore and mangrove habitats using Hanna $\mathrm{pH}$ meter instruments for $\mathrm{pH}$ and temperature measurement, Hanna salinity meter for salinity measurement, and Genway conductivity meter for conductivity determination.

\section{Population Density and Relative Abundance}

Plankton was identified by examining collected water samples by Zeiss Research Microscope. For each plankton group, a number of individuals at a $1 \mathrm{~mL}$ water sample determines the population density. The ratio of population density of each planktonic group to total densities of all examined groups was the calculated relative abundance.

\section{Species Richness}

Species richness (R) quantifies how many different types the dataset of interest contains (Jost 2006, Tuomisto 2010).

Table 1: Sampling Stations of zooplankton.

\begin{tabular}{|lll|}
\hline Location & Station & Transect \\
\hline Jazan & $\begin{array}{l}\text { Almarjan sandy shore (Salwa } \\
\text { coast) S1 }\end{array}$ & $16.838854,42.572049$ \\
Jazan & $\begin{array}{l}\text { Almarjan mangrove (Turfa } \\
\text { peninsula) S2 }\end{array}$ & $17.157910,42.365550$ \\
\hline
\end{tabular}

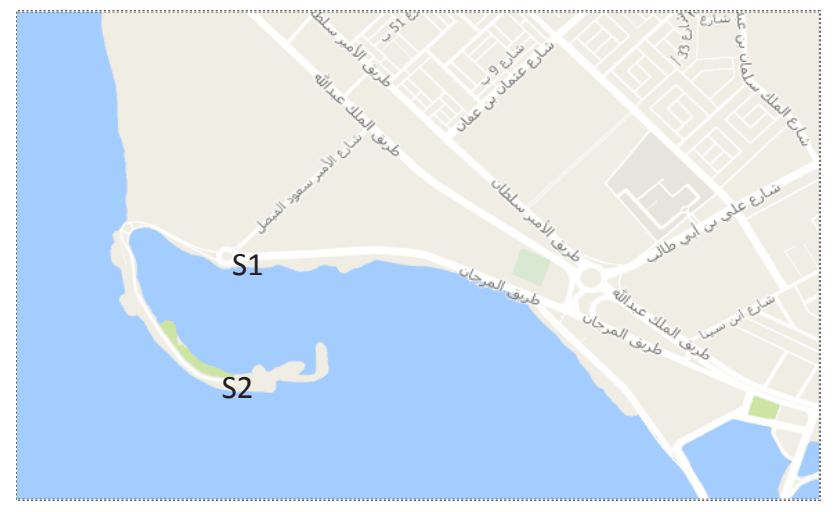

Fig. 1: Map showing the study area.

It calculates the number of different invertebrate species in each of the studied areas.

\section{Statistical Analysis}

ANOVA (analysis of variance) was applied using SPSS 22 statistical software program to determine the significance of the spatial distribution of planktonic organisms at the investigated area. $\mathrm{P}<0.05$ was selected as the minimum significance level for statistical analysis. Regression analysis was used to examine the effect of water criteria on zooplankton abundance at both studied sites.

\section{RESULTS AND DISCUSSION}

\section{Water Criteria at Different Seasons}

The mean seasonal values of $\mathrm{pH}$, salinity, water temperature, and conductivity were detected at Almarjan sandy shore (Table 1) and mangrove (Table 2) studied sites.

\section{Species Richness}

The variable richness of zooplankton species was demonstrated during different seasons at Almarjan sandy shore and mangrove studied sites.

At the intertidal zone of sandy shore, species richness was 8 in summer, 5 in autumn, 4 in winter, and 7 in spring seasons. Species richness at mangroves was 7 in summer, 4 in autumn, 6 in winter, and 7 in spring seasons.

\section{Identified Zooplankton}

At the intertidal zone of Almarjan sandy shore. Ciliates were the defined protozoan zooplankton. Metazoan zooplankton were nematodes, copepods, rotifers, planaria, kinorhyncha, nauplius larva, and veliger larva.

At Almarjan mangrove, collected metazoan zooplankton were nematodes, copepod, planaria, gnathostomulida, 
Table 2: Mean \pm SD of water criteria determined seasonally at Almarjan sandy shore site.

\begin{tabular}{|lllll|}
\hline & $\mathrm{pH}$ & water temperature & salinity & conductivity \\
\hline Winter & $7.773 \pm 0.304$ & $30.7 \pm 0.755$ & $32.267 \pm 0.702$ & $56.667 \pm 1.778$ \\
Spring & $7.55 \pm 0.266$ & $31.833 \pm 0.651$ & $34.833 \pm 3.041$ & $61.24 \pm 4.097$ \\
Summer & $7.947 \pm 0.142$ & $37.733 \pm 0.404$ & $38.367 \pm 0.603$ & $62.933 \pm 1.756$ \\
Autumn & $7.383 \pm 0.065$ & $31.5 \pm 0.866$ & $33.23 \pm 0.513$ & $59.967 \pm 1.137$ \\
\hline
\end{tabular}

Table 3: Mean \pm SD of water criteria determined seasonally at mangrove site.

\begin{tabular}{|lllll|}
\hline & $\mathrm{pH}$ & water temperature & Salinity & Conductivity \\
\hline Summer & $8.02 \pm 0.094$ & $38.33 \pm 1.885$ & $39.97 \pm 1.026$ & $63.93 \pm 2.783$ \\
Autumn & $7.38 \pm 0.105$ & $30.2 \pm 0.36$ & $33.71 \pm 0.813$ & $61.4 \pm 0.552$ \\
Winter & $7.44 \pm 0.05$ & $27.5 \pm 2.082$ & $32 \pm 0.816$ & $58.625 \pm 0.873$ \\
Spring & $7.48 \pm 0.07$ & $30.7 \pm 0.557$ & $34.33 \pm 1.527$ & $61.08 \pm 2.973$ \\
\hline
\end{tabular}

Table 4: Mean seasonal abundance of zooplankton at the intertidal zone of sandy shore habitat at Almarjan coastal zone.

\begin{tabular}{|lllll|}
\hline Species & $\begin{array}{l}\text { Summer } \\
\text { mean } \pm \text { SD }\end{array}$ & $\begin{array}{l}\text { Autumn } \\
\text { mean } \pm \text { SD }\end{array}$ & $\begin{array}{l}\text { Winter } \\
\text { mean } \pm \text { SD }\end{array}$ & $\begin{array}{l}\text { Spring } \\
\text { mean } \pm \text { SD }\end{array}$ \\
\hline Ciliates & $140 \pm 18.257$ & $122.33 \pm 4.041$ & $94.6 \pm 7.335$ & $131 \pm 10.155$ \\
Nematoda & $132.5 \pm 9.574$ & $77.33 \pm 6.028$ & $59 \pm 6.977$ & $106.67 \pm 11.547$ \\
Copepods & $102 \pm 14.142$ & $31.67 \pm 4.041$ & $43.67 \pm 4.041$ & $75 \pm 8.66$ \\
Nauplius larva & $78.667 \pm 7.64$ & - & - & $48.33 \pm 5.239$ \\
Veliger larva & - & - & - & $51.65 \pm 6.074$ \\
Water flea Cladocera & $100 \pm 3.605$ & $23.67 \pm 4.041$ & $21.67 \pm 3.512$ & $90.55 \pm 8.351$ \\
Rotifers & $89.667 \pm 4.51$ & & - & $83.33 \pm 10.82$ \\
Planaria & $46.667 \pm 4.041$ & $25.33 \pm 3.055$ & - & - \\
Kinorhyncha & $32.5 \pm 2.082$ & - & 218.94 & - \\
Total & 721.001 & 260.33 & & 595.53 \\
\hline
\end{tabular}

nauplius larva, trochophore larva, and fish larva. Ciliates were the identified protozoan zooplankton.

\section{Zooplankton Seasonal Abundance}

Population density of zooplankton collected at summer, autumn, winter, and spring seasons from Almarjan sandy shore and mangrove coastal zone was tabulated in Table 3 and Table 4 respectively.

Ciliates were the most abundant zooplankton on the sandy shore, while Kinorhyncha was the least abundant. At the Almarjan mangrove, Nematode was the most abundant zooplankton, whereas Gnathostomulida was the least abundant.

Two factors ANOVA showed a significant effect of species $(\mathrm{P}<0.001)$, season $(\mathrm{P}<0.001)$, and interactions of season and species $(\mathrm{P}>0.001)$ on zooplankton abundance at intertidal zone of Almarjan sandy shore.

Two factor ANOVA showed a significant effect of species $(\mathrm{P}<0.001)$, season $(\mathrm{P}<0.001)$, and interactions of season and species $(\mathrm{P}<0.001)$ on zooplankton abundance at the intertidal zone of Almarjan mangrove.
As given from Table 6 zooplankton diversity index was mostly higher in sandy shore than mangrove habitat. Diversity was peaked in summer for sandy shore habitat and spring for mangrove habitat. The Autumn season showed the lowest diversity index for zooplankton in both studied areas.

Zooplankton density and species richness were peaked at the summer season for the intertidal zone of Almarjan sandy shore and mangrove sites.

Based on relative abundance (Fig. 2) the protozoan ciliates were the highest abundant zooplankton at Almarjan sandy shore. Nematodes were the most abundant metazoan zooplankton, while Kinorhyncha was the least abundant. At Almarjan mangrove (Fig. 3) nematodes were the highest abundant zooplankton and gnathostomulida was the least abundant.

Based on abundance data (Table 4 and Fig. 2) zooplankton at summer season can be arranged at the intertidal zone of the sandy shore region as follows:

Ciliates $>$ Nematods $>$ Copepodes $>$ Planaria $>$ water flea (cladocera) $>$ Nauplius larva $>$ Kinorhynca. 


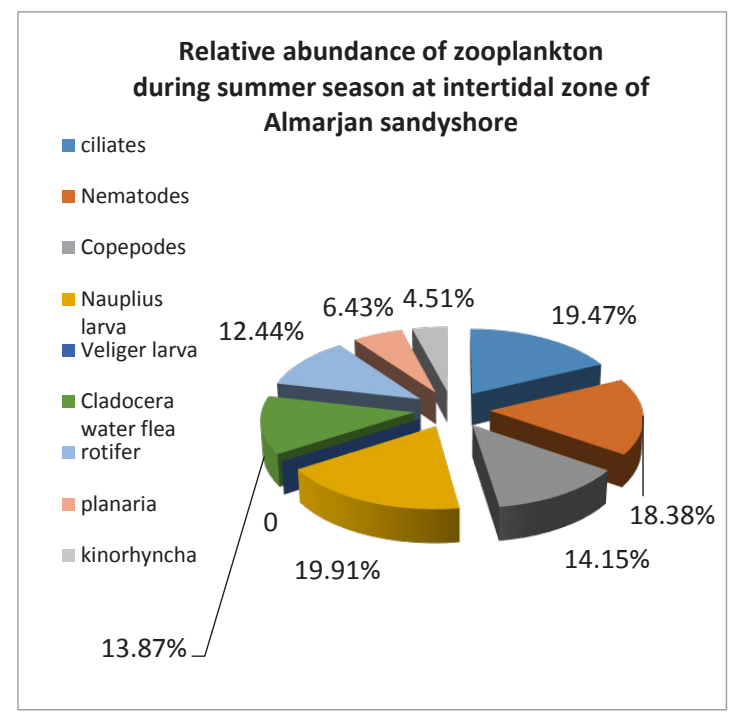

(a)

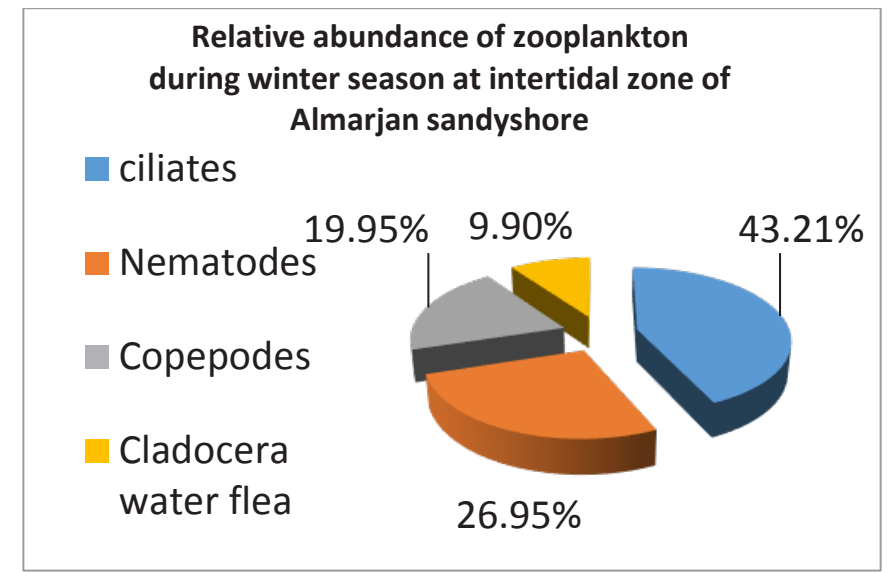

(c)

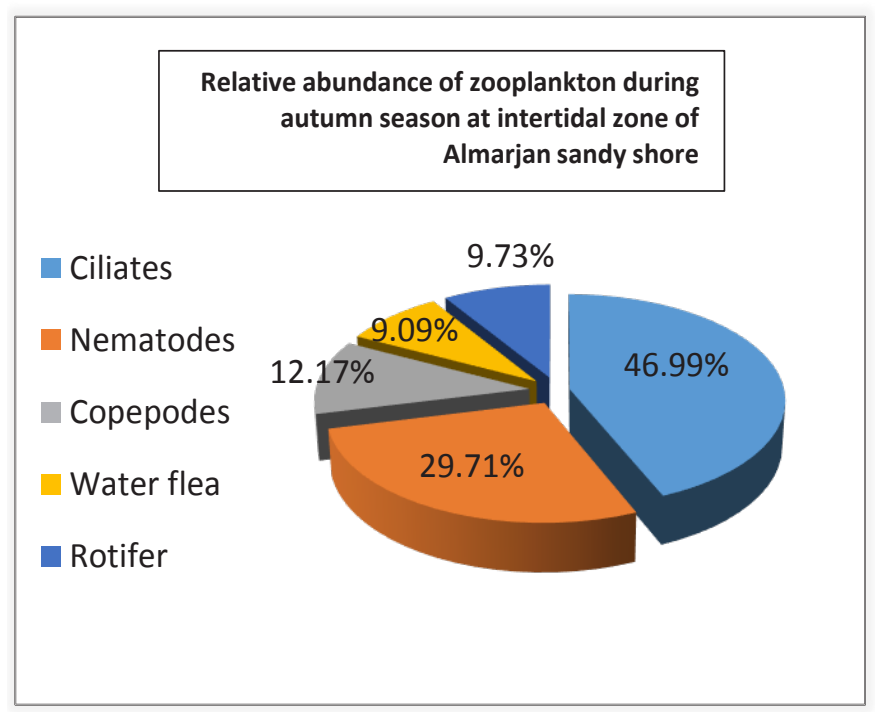

(b)

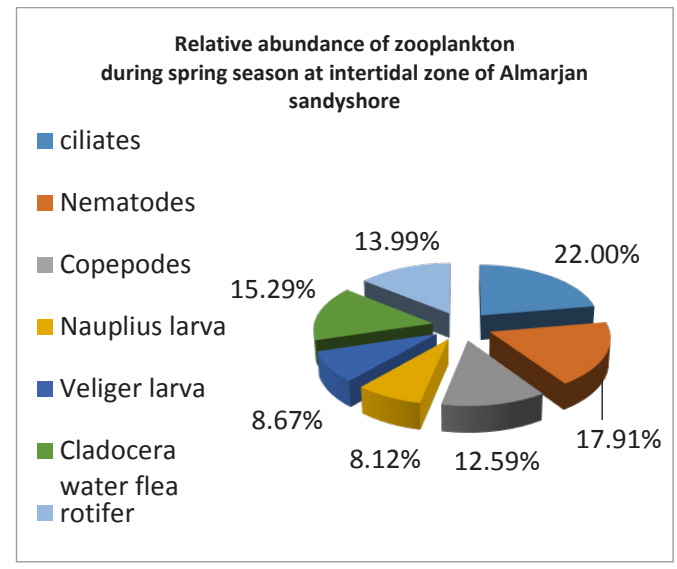

(d)

Fig. 2: Seasonal variation of percentage composition of zooplankton at the intertidal zone of Almarjan sandy shore a- summer season, b-autumn season, c-winter season, d-spring season.

Table 5: Mean seasonal abundance of zooplankton at the intertidal zone of Almarjan mangrove coastal zone.

\begin{tabular}{|lllll|}
\hline species & $\begin{array}{l}\text { Summer } \\
\text { mean } \pm \text { SD }\end{array}$ & $\begin{array}{l}\text { Autumn } \\
\text { mean } \pm \text { SD }\end{array}$ & $\begin{array}{l}\text { Winter } \\
\text { mean } \pm \text { SD }\end{array}$ & $\begin{array}{l}\text { Spring } \\
\text { mean } \pm \text { SD }\end{array}$ \\
\hline Ciliates & $113.75 \pm 24.96$ & $103.67 \pm 4.04$ & $78.33 \pm 7.64$ & $85.75 \pm 7.073$ \\
Nematoda & $132.67 \pm 11.15$ & $117.67 \pm 3.05$ & $87.75 \pm 5.31$ & $82.2 \pm 4.651$ \\
Copepods & $65.33 \pm 4.163$ & $49 \pm 3.61$ & $81.2 \pm 6.76$ & $72.75 \pm 5.188$ \\
Nauplius larva & $78.33 \pm 7.63$ & & $31 \pm 1.826$ & $42.67 \pm 11.01$ \\
Planaria & $43.365 \pm 6.43$ & $24.714 \pm 4.89$ & - & - \\
Gammarus & $95 \pm 5.568$ & - & - & - \\
Trochophore larva & - & - & $8 \pm 2.16$ & $13.25 \pm 2.75$ \\
Fish larva & - & - & & $36.25 \pm 4.79$ \\
Gnathostomulida & $29.33 \pm 1.527$ & - & $16.8 \pm 1.702$ & $40 \pm 5.305$ \\
Total & 557.775 & 295.05 & 303.08 & 372.87 \\
\hline
\end{tabular}




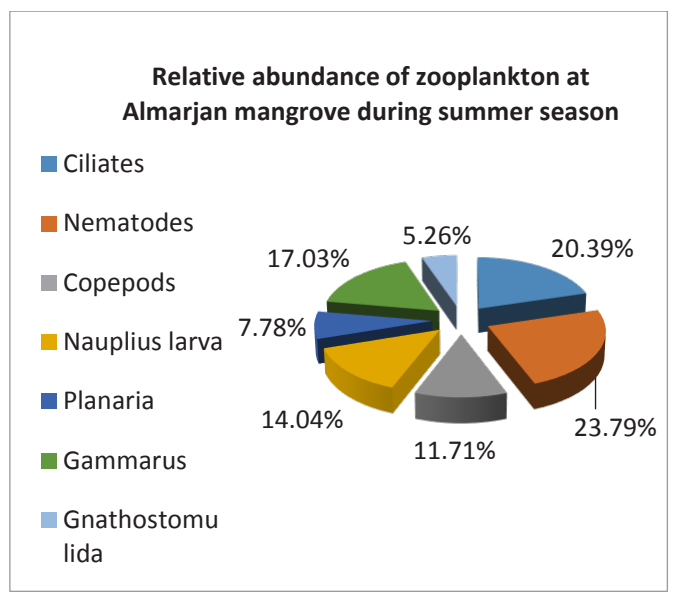

(a)

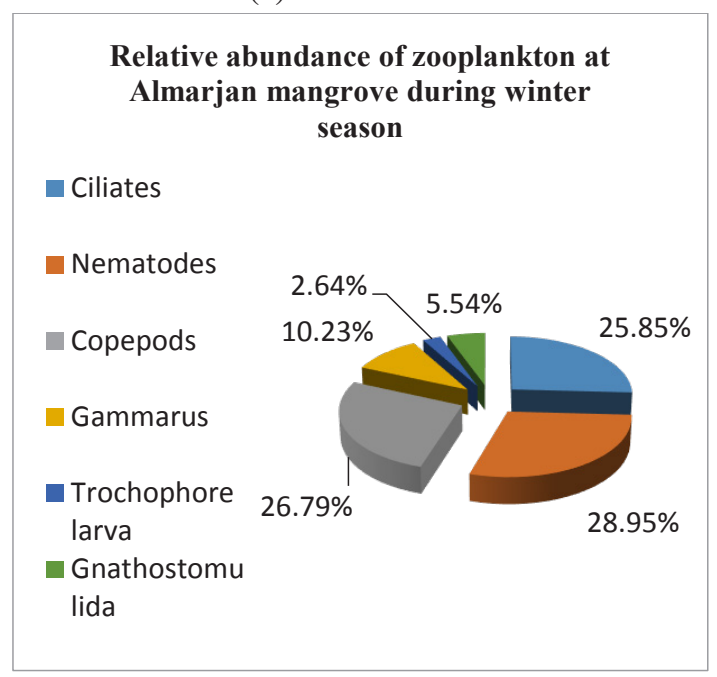

(c)

\section{Relative abundance of zooplankton at Almarjan mangrove during autumn season}

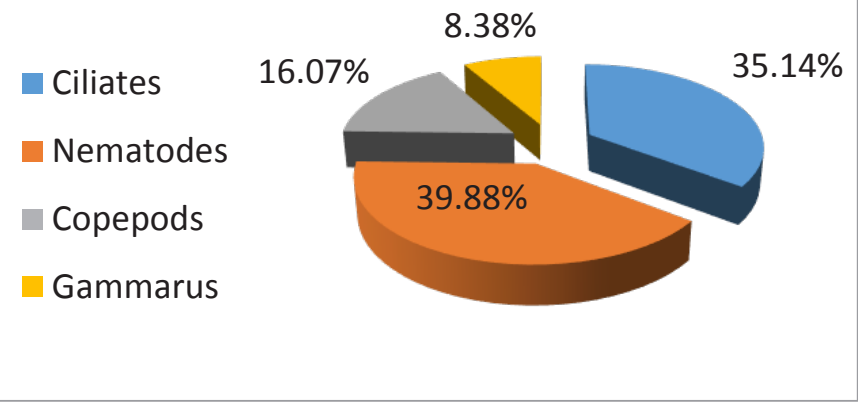

(b)



(d)

Fig. 3: Seasonal variation of percentage composition of zooplankton at Almarjan mangrove, a-Summer season b-autumn season c-winter season d-spring season.

At mangrove (Table 5 and Fig. 3). zooplankton was ranked as follows:

Nematods $>$ ciliates $>$ Gammarus $>$ nauplius larva $>$ copepods $>$ Planaria $>$ Gnathostomulida

Total zooplankton abundance data (Fig 4) showed higher population density for sandy shore in summer and spring

Table 6: Shannon-Weiner diversity index $\left(\mathrm{H}^{\prime}\right)$ of zooplanktons at Almarjan sandy shore and mangrove.

\begin{tabular}{|lll|}
\hline Season & Sandy shore & Mangrove \\
\hline Summer & 0.9 & 0.709 \\
Autumn & 0.688 & 0.536 \\
Winter & 0.548 & 0.672 \\
Spring & 0.835 & 0.789 \\
\hline
\end{tabular}

seasons. One-way ANOVA showed a significant difference $(\mathrm{P}<0.05)$ between total zooplankton density at the intertidal zone of sandy shore and mangrove investigated sites. Duncan's comparison of means test demonstrated that total zooplankton density at the sandy shore was significantly ( $\mathrm{P}$ $<0.05)$ higher than at the mangrove site.

\section{Effect of Water Criteria on Seasonal Abundance of Zooplankton}

Regression analysis between measured water criteria and seasonal zooplankton abundance was calculated.

regression analysis of water criteria with zooplankton abundance inhabiting intertidal zone at Almarjan sandy shore showed nonsignificant relationship with $\mathrm{pH}(\mathrm{r}=0.48$, $\mathrm{p}>0.05)$, Salinity showed significant relationship $(r=0.931$, 




Fig. 4: Seasonal abundance of zooplankton at the intertidal zone of Almarjan sandy shore and mangrove coastal zones.

$\mathrm{p}=0.03$ ). Surface seawater temperature (SST) demonstrated significant effect on zooplankton abundance $(r=0.948$, $\mathrm{p}<0.05$ ). Conductivity showed no significant difference $(\mathrm{r}=0.958, \mathrm{p}>0.05)$. At Almarjan mangrove; regression relationship was significant $(\mathrm{r}=0.922, \mathrm{P}<0.05)$ between seasonal variation in SST and zooplankton abundance. Salinity demonstrated significant regression relationship $(r=0.970, P<0.05)$ with zooplankton abundance. Significant relationship $(\mathrm{r}=0.983, \mathrm{p}<0.05)$ was shown between $\mathrm{pH}$ and zooplankton abundance. No significant regression was shown between conductivity and zooplankton abundance $(\mathrm{r}=0.838, \mathrm{p}>0.05)$.

\section{DISCUSSION}

Few works referred to zooplankton in Jazan. However, no previous study concerned the identification of zooplankton species in the Jazan coastal area. It was stated that zooplankton acquires the necessary energy amount required to perform vital activities (Lee \& Stokes 2006).

Zooplankton community structure was studied by several authors as bioindicators for global climatic changes due to their sensitivity to environmental stressors. Qualitative and quantitative analysis of the zooplankton community, bioindicator species were selected for analysis of water quality (Ferdous \& Muktadir 2009, AbdAllah 2017, Kim et al. 2020). Paul et al. (2016) used zooplankton abundance for the evaluation of abiotic stressors in the temperate estuarine ecosystem. Change in zooplankton abundance at studied habitats might be attributed to the occurrence of inorganic and organic contaminants (Mahdy 2005, ObuidAllah et al. 2005).

Al-Asgah and Bedawi (1988) studied Zooplankton at Jazan Reservoir and recorded copepod, water flea, and rotifers. The present study reported the same groups of zooplanktons. Zooplankton reached their maximum abundance in the summer season. This agrees with previous studies (AlAsgah \& Bedawi 1988, Gaughan \& Potter 1995).
Bakhsh (1994) stated that the food content of the thread bream Nemipterus japonicus at Farsan Islands and Jazan seawater included copepods and amphipods. This result agrees with those of the current study where both zooplankton groups were found.

Calanoid and Euphausiid zooplankton are important zooplankton in the red sea (ObuidAllah et al. 2005). Farasan report stated the presence of copepod as zooplankton in the surface seawater (Abou-Zinada 2001). The current study is in accordance with this study and demonstrated the presence of a high population density of copepod as a holoplankton at the littoral area of sandy and muddy shore.

Surface water temperature, $\mathrm{pH}$, and conductivity had a significant effect on zooplankton abundance. This finding agrees with the previous study by Sharma \& Kumari (2018) and Manickam et al. (2018) who found a significant effect of temperature, $\mathrm{pH}$, and salinity on zooplankton diversity in Ukkadam lake.

In the present work, Copepods and ciliates were the most abundant zooplankton in both mangrove and sandy shore intertidal zone. A high number of nematodes was observed among the zooplankton composition at the intertidal zone of sandy or muddy shore studied habitats. This might be due to that the sampling site was the surface water overlying sediments where seawater passed in and out of the underlying sediments. The results agree with Jensen (1981) and Vanreusel et al. (1992) who stated that nematodes exist in different aquatic freshwater or marine habitats. They reported about 4000 diverse marine nematode planktonic species. The presence of vast zooplankton assemblage recorded in the present study indicates good water criteria as zooplankton are sensitive to seasonal changes (Rombouts et al. 2013, Manickam et al. 2018, Xiong et al. 2020).

Future research will focus on the factors and threats that influence zooplankton population density in Jazan coastal habitats.

\section{CONCLUSION}

The present work was made due to the shortage of information about the identification of zooplankton in the Jazan coastal zone. The maximum species richness and abundance of collected zooplankton were found in the summer season, whereas the least species richness and abundance of collected zooplankton were found in the winter season. Variable abundance and species richness were shown at different seasons for sandy shore and mangrove studied sites. Water temperature, salinity, and conductivity showed a significant effect $(\mathrm{P}<0.05)$ on zooplankton density and species richness. 


\section{ACKNOWLEDGEMENT}

The authors are thankful to the scientific Dean of Jazan University for financially supporting that work as a part of the six scientific programs, grant number 4357.

\section{REFERENCES}

AbdAllah, A.T. 2017. The efficiency of invertebrate animals for risk assessment and biomonitoring of hazardous contaminants in the aquatic ecosystem, A review, and status report. J. Environ. Risk Assess. Remed., 1(1): 13-18.

Abdul Azis, P. K., Al- Tisan, I. A., Daili, M.A., Green, T .N., Dalvi, A. G. I. and Javeed, M. A. 2003. Chlorophyll and plankton of the gulf coastal waters of Saudi Arabiabordering a desalination plant. Desalination, $154 ; 291-302$.

Abu-Zinada, A.H. 2001. First Saudi Arabian National Report on the Convention on Biological Diversity. The National Commission for Wildlife Conservation and Development.

Al-Asgah, N. A. and Bedawi, R. M. 1988. Some observations on water quality and aquatic fauna of the Gizan reservoir in Saudi Arabia. J. Coll. Agric. King Saud. Univ., 10(2): 357-362.

Bakhsh, A.A. 1994. The biology of thread bream Nemipterus japonicas (Bloch) from the Jizan region of the Red Sea. J. Kua. Mar. Sci., 7: 179-189.

Bradford-Grieve, J.M. Haakonsen, L. and Jillett, J.B. 1983. The marine fauna of New Zealand: pelagic calanoid copepods: Families Euchaetidae, phaemidae, scolecithricidae, diaixidae, and tharybidae. Oceanogr.Inst., 90: 1-150.

Castro, P. and Huber, M. 2012. Marine Biology. 9th Edition. McGraw Hill Publishers, New York.

Farasan Report. 2000. Islands protected area master management plan 2000. National Commission for Wildlife Conservation and Development, Riyadh, 11575.

Ferdous, Z. and Muktadir, A.K.M. 2009. A review: Potentiality of zooplankton as bioindicator. American J. Appl. Sci., 6(10): 18151819.

Gaughan, D. and Potter, C. 1995. Composition, distribution, and seasonal abundance of zooplankton in a shallow, seasonally closed estuary in temperate Australia. Estuar. Coast. Shelf Sci., 41(2): 117-135.

Jensen, P. 1981. Description of the freeliving marine nematode Dracognomus tinae n. sp. (Draconematoidea: Prochaetosomatidae). Cah. Biol. mar. XXII: 285-289.

Jost, L. 2006. Entropy and diversity. Oikos, 113, 363-375.

Heron, G. A. and Bradford-Grieve, J. M. 1995. The marine fauna of New Zealand. Oceanogr. Inst., 104: 1-57.
Hickman, C.P., Roberts, L.S., Keen, S.L., Larson, A., l'Anson, H. and Eisenhour, D.J. 2011. Integrated Principles of Zoology.15thedition. Mc-Graw Hills Higher Education Publishers. Boston, Madrid.Kim, H., Lee, C., Lee, S., Oh, S. and Kim, W. 2020. Biodiversity and community structure of mesozooplankton in the marine and coastal national park areas of Korea. Diversity, 12: 233

Lee, G. and Stokes, J. 2006. Marine Science. An illustrated guide to Science. Chelsea House Publishers, New York.

Mahdy, A.A. 2005. Taxonomical and Ecological Studies on Marine Zooplankton of the Red Sea, Egypt. MSc. Thesis, Al-Azhar University, Assiut, Egypt.

Manickam, N., Bhavan, P.S., Santhanam, P., Bhunasweri, R., Muralisankar, T., Srinivasan, V., Assiakkutti, A., Rajkumar, G., Udayasuriyan, R. and Karthik, M. 2018. Impact of seasonal changes in zooplankton biodiversity in Ukkadam Lake, Coimbatore, Tamil Nadu, India, and potential future implications of climate change. JoBAZ, 15: 79.

Nybakken, J. W. 1997. Marine Biology an Ecological Approach. 4th Edition Addison-Wesley Educational Publishers Inc., Boston, p. 481.

ObuidAllah, A.H., AbdAllah, A.T., Abu-Eldahab, H.M., Abdul-Rahman, N.S. and Mahdy, A.A. 2005. Impact of heavy metal contamination on seasonal abundance of planktonic copepods inhabiting mangrove areas in Safaga, Red Sea, Egypt. Egyp. J Exper. Biol., 1: 57-66.

Paul, S., Wooldridge, T. and Perissinotto, R. 2016. Evaluation of abiotic stresses of temperate estuaries by using resident zooplankton: A community vs. population approach. Estuar. Coast. Shelf Sci., 170: 102-111.

Rombouts, I., Beaugrand, G., Artigas, L.F., Dauvin, J. C., Gevaert, F, Goberville, E., Kopp, D., Lefebvre, S., Luczak. C., Spilmont, N., Travers-Trolet, M., Villanueva, M.C. and Kirby, R.R. 2013. Evaluating marine ecosystem health: Case studies of indicators using direct observations and modeling methods. Ecol. Indicators, 15: 353-365.

Sharma, R.C. and Kumari, R. 2018. Seasonal variation in zooplankton community and environmental variables of sacred Lake Prashar Himachal Pradesh, India. Int. J. Fish. Aquat. Stud., 6(2): 207-213.

Tuomisto, H. 2010. A diversity of beta diversities: straightening up a concept gone awry: Part 1 . Defining beta diversity as a function of alpha and gamma diversity. Ecography, 33: 2-22.

Vanreusel, A., Vincx, M., Van Gansbeke, D. and Gijselinck, W. 1992. Structural analysis of the meiobenthic communities of the shelf break area in two stations of the Gulf of Biscay (N.E. Atlantic). Belg. J. Zool., 122: 184-202.

Xiong, W., Xuena, H., Chen, Y., Fu, R., Duu, X. Chen, X. and Zhan, A. 2020. Zooplankton biodiversity monitoring in polluted freshwater ecosystems: A technical review. Environ. Sci. Technol., 5(1): $1-11$. 